\title{
Graft Compatibility among Chestnut (Castanea) Species
}

\author{
Hongwen Huang, J.D. Norton, G.E. Boyhan, and B.R. Abrahams \\ Department of Horticulture, Auburn University, AL 36849
}

Additional index words. incompatibility, isoperoxidase, Castanea mollissima, C. dentata, C. crenata, phloem-fibrous-bundle

\begin{abstract}
Graft compatibility was investigated for 15 Chinese chestnut (Castanea mollissima Bl.) cultivars, nine American chestnut [C. dentata (Marsh.) Borkh.] selections, six Japanese chestnut (C. crenata Sieb.) cultivars, and two putative Japanese hybrids on two known rootstocks of Chinese chestnut. Intraspecific grafting of Chinese chestnut resulted in $80 \%$ success after two growing seasons. An unusual anatomical structure of the chestnut stem had a significant effect on graft success. The phloem fiber bundles related to graft failure are described in the study. Interspecific grafts of seven American and five Japanese chestnut selections resulted in $\geq 70 \%$ success. The putative Japanese hybrids had a significantly lower success rate $(<50 \%)$ regardless of rootstocks. A marked graft incompatibility was found in one Japanese/Chinese and two American/Chinese combinations. Graft incompatibility related to morphological abnormalities at the graft union was also observed in interspecific grafts. Comparisons of cambial isoperoxidase isozymes between successful and unsuccessful grafts did not support the hypothesis that peroxidase isozymes are indicators of rootstock-scion compatibility. The results suggest that genetic incompatibility is not a major cause of graft failure in Chinese chestnut.
\end{abstract}

Grafting has proven to be a more successful and feasible method of asexually propagating chestnut than any other technique in the chestnut industry (Keys, 1978; McKay and Jaynes, 1969). However, a major problem associated with grafting chestnuts is incompatibility between the scions of named cultivars and undefined rootstocks. McKay's early work (1947) demonstrated that considerable variation in grafting success occurred in Chinese chestnut (Castanea mollissima). These results contradict the observations of Stoke (1961) who found that all Chinese chestnut cultivars grafted on Chinese chestnut seedlings were successful. Weber and MacDaniels (1969) indicated that incompatibility commonly occurred with interspecific grafts. The causes of graft incompatibility are not known because a limited number of graft experiments have been conducted (Woodroof, 1979).

An important aspect related to graft incompatibility may be that the source of rootstock for graft propagation is often not sufficiently characterized. Most U.S. chestnut nurseries keep three to four species in their stock plantings (Bergnatz, 1987) and chestnut species hybridize freely when planted near each other. This results in a rootstock source of seedlings from mixed genotypic background, which could be a major contributing factor in graft failure. Jaynes (1979) has recommended as a standard practice that chestnut nurseries use rootstock seedlings grown from the seed of the cultivar to be grafted, to decrease the chances of graft incompatibility (hybridity-related or otherwise).

Chinese chestnut has been successfully grafted for centuries in Asiatic countries (Hardy, 1960) without selection of rootstocks. The largest chestnut producer is China, with $40 \%$ of world production. Millions of trees are grafted each year with no significant incompatibility in Chinese chestnut (Rutter et al., 1990). Despite general compatibility in the Chinese species, there still is approximately 5\% graft incompatibility in China (Zhang et al., 1987). Incompatibility among species also exists in China: Attempts to graft Chinese on seguin chestnut (C. seguinii Dode.) resulted in complete failure (Liu et al., 1988).

Received for publication 3 Dec. 1993. Accepted for publication 2 Mar. 1994 Journal no. 11-933532 of the Alabama Agricultural Experiment Station. We thank Philip Rutter for his valuable suggestions during manuscript preparation. The cost of publishing this paper was defrayed in part by the payment of page charges. Under postal regulations, this paper therefore must be hereby marked advertisement solely to indicate this fact.
Experiments in China to uncover the reasons for the graft failure in Chinese chestnut indicated that the unique structure of the chestnut stem is the major cause of graft failure (Liu et al., 1988). Because wood of the stem is fluted or grooved, the cambium of the scion and rootstock often do not join uniformly (Woodroof, 1979).

In recent years, commercial chestnut nurseries in Florida and California have increased sales of grafted trees in response to market demand. The nurseries are concerned about the risk of incompatibility due to lack of information from inter- and intraspecific grafting experiments (Lagerstedt, 1987), and in the long term any significant development of a chestnut industry will require a reliable method of asexual propagation.

A recent finding of a relationship between graft incompatibility and cambial peroxidase isozyme patterns in Chinese chestnut suggests that the matching of isoperoxidase bands between cultivar and rootstock could be used as an index for chestnut graft propagation (Santamour, 1988: Santamour et al., 1986).

This study was designed to 1) evaluate graft compatibility in Chinese chestnut cultivars; 2) determine the effects of phloem fiber bundles on graft failure; 3 ) compare short-term graft compatibility of American chestnut (C. dentata) and Japanese chestnut (C. crenata) on Chinese chestnut rootstocks; and 4) test the reported relationship between cambial isoperoxidase banding patterns and graft compatibility.

\section{Materials and Methods}

Scion source. A total of 32 genetically diverse cultivars or selections of $C$. dentata, $C$. mollissima, and $C$. crenata species were used as scions in this study. Scions from nut-bearing $C$. dentata trees were collected at different locations in the U.S. during the winter of 1991 to 1992: seven clonal selections from West Salem, Wis. (WS); one from Hesper, Iowa (Hesper) and one from Shinbone Valley, Alabama (Shinbone). Scions of 15 widely grown cultivars were collected at the China National Chestnut Germplasm Plantation, Shandong, People's Republic of China, in Feb. 1992. These cultivars were selected from four distinct regional cultivar groups of $C$. mollissima and represent a broad diversity of germplasm of $C$. mollissima (Table 1). Eight $C$. crenata selections and hybrids were used. These scions were collected in Jan. and Feb. 1992 and included J-R34T6 and J-R7T7 
Table 1. Grafting success of 15 Chinese chestnut cultivars on AU-17 seedlings Chinese chestnut rootstocks.

\begin{tabular}{|c|c|c|c|c|c|}
\hline Cultivar group & \multicolumn{3}{|c|}{ Cultivar } & \multicolumn{2}{|c|}{$\begin{array}{l}\text { Grafts growing } \\
\text { successfully }(\%)^{z}\end{array}$} \\
\hline \multirow{7}{*}{$\begin{array}{l}\text { Chang Jiang river } \\
\text { region }\end{array}$} & \multicolumn{3}{|c|}{ Jiaozha } & \multicolumn{2}{|r|}{$80 b^{y}$} \\
\hline & \multicolumn{3}{|c|}{ Jiujiazhong } & \multicolumn{2}{|r|}{$70 \mathrm{bc}$} \\
\hline & \multicolumn{3}{|c|}{ Yangmaoli } & \multicolumn{2}{|c|}{$100 \mathrm{a}$} \\
\hline & \multicolumn{3}{|c|}{ Liuyuebao } & \multicolumn{2}{|c|}{$100 \mathrm{a}$} \\
\hline & \multicolumn{3}{|c|}{ Yelicang } & \multicolumn{2}{|c|}{$0 \mathrm{~d}$} \\
\hline & \multicolumn{3}{|c|}{ Zaozhuang } & \multicolumn{2}{|c|}{$40 \mathrm{c}$} \\
\hline & \multicolumn{3}{|c|}{ Jianding } & \multicolumn{2}{|c|}{$100 \mathrm{a}$} \\
\hline \multirow[t]{4}{*}{ Northern region } & \multicolumn{3}{|c|}{ Hongguang } & \multicolumn{2}{|c|}{$100 \mathrm{a}$} \\
\hline & \multicolumn{3}{|c|}{ Yanhong } & \multicolumn{2}{|c|}{$100 \mathrm{a}$} \\
\hline & \multicolumn{3}{|c|}{ Haifeng } & \multicolumn{2}{|c|}{$100 \mathrm{a}$} \\
\hline & \multicolumn{3}{|c|}{ Jinfeng } & \multicolumn{2}{|r|}{$67 \mathrm{bc}$} \\
\hline \multirow[t]{3}{*}{ Southeast region } & \multicolumn{3}{|c|}{ Changcibanhong } & \multicolumn{2}{|c|}{$80 \mathrm{~b}$} \\
\hline & \multicolumn{3}{|c|}{ Shangguang } & \multicolumn{2}{|c|}{$100 \mathrm{a}$} \\
\hline & \multicolumn{3}{|c|}{ Duancibanhong } & & $67 \mathrm{bc}$ \\
\hline Southwest region & & Zhongguoho & ongpi & & $80 \mathrm{~b}$ \\
\hline $\begin{array}{l}\overline{{ }^{2} \text { Percent based on }} \\
{ }^{\mathrm{y}} \text { Mean separation }\end{array}$ & $\begin{array}{l}30 \text { trees } \\
n \text { colum }\end{array}$ & $\begin{array}{l}\text { grafted with } \\
\text { in by Duncan }\end{array}$ & $\begin{array}{l}\text { double g } \\
\text { s multip }\end{array}$ & s. & $\mathrm{t}, P=0.05$ \\
\hline $\begin{array}{l}\text { Table } 2 . \text { The influe } \\
\text { cultivars on the }\end{array}$ & $\begin{array}{l}\text { nce of ph } \\
\text { seedling }\end{array}$ & $\begin{array}{l}\text { loem fiber } b \\
\text { gs raised fror }\end{array}$ & $\begin{array}{l}\text { ndle on } \\
\text { the sa }\end{array}$ & $\begin{array}{l}\text { ft success } \\
\text { cultivars. }\end{array}$ & s of Chinese \\
\hline & No. of & No. of & grafts su & iving after & r grafting \\
\hline Cultivar & grafts & 1 month & 4 montl & 6 months & 14 months \\
\hline & Graftec & d on fiber bu & indle sect & & \\
\hline AU-Homestead & 50 & 20 & 8 & 8 & 0 \\
\hline AU-Cropper & 50 & 25 & 12 & 10 & 0 \\
\hline AU-17 & 50 & 32 & 17 & 6 & 2 \\
\hline & Grafted & on nonfiber & bundle se & & \\
\hline AU-Homestead & 50 & 45 & 44 & 44 & 44 \\
\hline AU-Cropper & 50 & 49 & 47 & 47 & 47 \\
\hline AU-17 & 50 & 48 & 48 & 48 & 48 \\
\hline
\end{tabular}

from the Connecticut Agricultural Experiment Station; two putative $C$. crenata hybrids $\mathrm{CT}^{\#}$ and $\mathrm{CT} 2^{\#}$ (seedling selections from seeds of interspecifically open-pollinated tree of $C$. crenata) from the Empire Chestnut Company, Ohio; and four other C. crenata cultivars from the Hubei Academy of Agricultural Science, People's Republic of China.

Scionwood was wrapped with damp paper towels, sealed in plastic bags, and shipped by air mail or delivered in ice-cooled insulated boxes within 3 to 5 days. All scions were then stored at $4 \mathrm{C}$ until use.

Rootstocks. Seedlings from C. mollissima AU-Homestead and AU-17 were used as rootstocks in this study. Seeds were collected from the chestnut breeding orchard at Auburn University, Alabama, which is isolated from other chestnut pollen sources. All of the trees in the orchard were pure C. mollissima introduced from China around 1933 by the U.S. Dept. of Agriculture. Seedlings were grown in 18.93-liter polyethylene containers using a 6 pine bark : 1 sand medium (v/v) amended with $8.4 \mathrm{~kg}$ Osmocote 17-7$12,3.5 \mathrm{~kg}$ dolomitic limestone, and $1.2 \mathrm{~kg}$ Micromax per $\mathrm{m}^{3}$. All seedlings were 1 year old and $\approx 10 \mathrm{~mm}$ in diameter at graft junction at the time of grafting.

Experimental design and grafting method. Four experiments were conducted. 1) Intraspecific graft compatibility in C. mollissima was investigated using 15 C. mollissima cultivars grafted on
Table 3. Grafting success of American (Castanea dentata) and Japanese chestnuts (C. crenata) on AU-17 Chinese chestnut seedlings.

\begin{tabular}{lcc}
\hline \hline Scion & $\begin{array}{l}\text { No. of } \\
\text { grafts }\end{array}$ & $\begin{array}{c}\text { Grafts growing } \\
\text { successfully }(\%)\end{array}$ \\
\hline WS-1 & \multicolumn{1}{c}{ C. dentata } \\
WS-R1 & 30 & $90 \mathrm{a}^{\mathrm{z}}$ \\
Shinbone & 30 & $83 \mathrm{ab}$ \\
WS-R2 & 30 & $97 \mathrm{a}$ \\
WS-Curly & 30 & $80 \mathrm{ab}$ \\
WS-Male sterile & 30 & $20 \mathrm{~d}$ \\
WS-E2 & 30 & $46 \mathrm{c}$ \\
WS-E1 & 30 & $70 \mathrm{~b}$ \\
Hesper & 30 & $93 \mathrm{a}$ \\
& 30 & $93 \mathrm{a}$ \\
Yinhong & C. crenata & \\
Toshan 60 & 30 & $90 \mathrm{a}$ \\
Toshan 9 & 30 & $93 \mathrm{a}$ \\
Kiasheng & 30 & $73 \mathrm{~b}$ \\
J-34T6 & 30 & $6 \mathrm{~d}$ \\
J-R7T7 & 30 & $90 \mathrm{a}$ \\
\end{tabular}

${ }^{\mathrm{z}}$ Mean separation in column by Duncan's multiple range test, $P=0.05$.

Table 4. Grafting success of American (Castanea dentata), Japanese ( $C$. crenata), and hybrid Japanese chestnuts on seedlings from two Chinese cultivars.

\begin{tabular}{lcc}
\hline \hline Rootstock & Scion & $\begin{array}{c}\text { Grafts growing } \\
\text { successfully }(\%)^{\mathrm{z}}\end{array}$ \\
\hline AU-17 & Shinbone & $93 \mathrm{a}^{\mathrm{y}}$ \\
& WS-1 & $90 \mathrm{a}$ \\
& J-R34T6 & $87 \mathrm{a}$ \\
& J-R7T7 & $80 \mathrm{ab}$ \\
& J-CT2 & $40 \mathrm{c}$ \\
Au-Homestead & J-CT1 & $33 \mathrm{c}$ \\
& Shinbone & $87 \mathrm{a}$ \\
& WS-1 & $87 \mathrm{a}$ \\
& J-R34T6 & $60 \mathrm{~b}$ \\
F significance & J-R7T7 & $50 \mathrm{bc}$ \\
Rootstocks (R) & J-CT2 & $46 \mathrm{c}$ \\
Scions (S) & J-CT1 & $43 \mathrm{c}$ \\
R $\times$ S & & \\
& & $* *$
\end{tabular}

$\overline{{ }^{2} \text { Percent based on } 30 \text { trees grafted with a single graft, except WS-1 and }}$ Shinbone with double grafts.

'Mean separation within each rootstock by Duncan's multiple range test, $P \leq 0.05$.

${ }^{*}, * *, * * * * 5$ Significant at $P \leq 0.05,0.01$, or 0.001 , respectively.

AU-17 seedlings (Table 1). Ten grafts were made for each scion/ rootstock combination, and replicated three times as blocks, based on 5- to 8-day intervals, in a randomized complete-block design. 2) The effect of cutting into phloem fiber bundles was investigated in three $C$. mollissima cultivars (Table 2). Fifty grafts of each cultivar were made by positioning the scions directly on the phloem fiber bundle section of the rootstock (Fig. 1B), and as a control 50 grafts were made by positioning scions between the fiber bundles. A completely randomized design was used. 3) Interspecific graft compatibility of $C$. dentata and $C$. crenata on $C$. mollissima rootstocks was investigated in 15 cultivars and selec- 


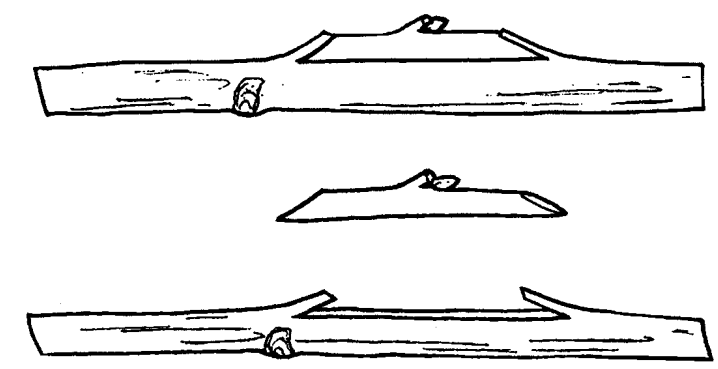

A

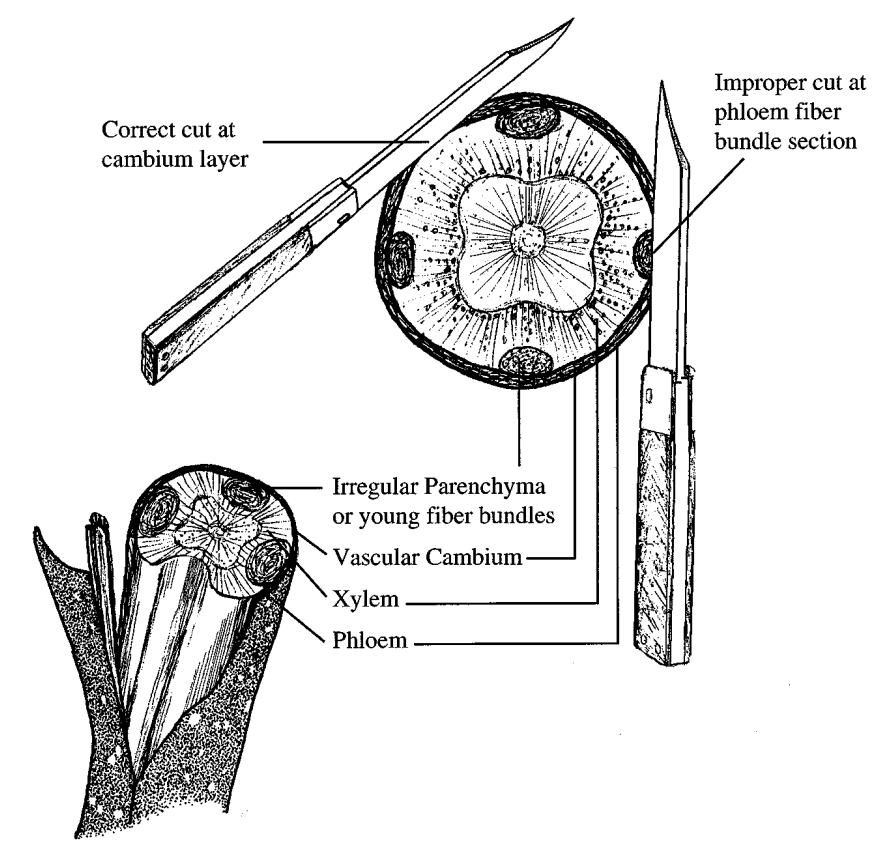

B

Fig. 1. A veneer side graft method for chestnuts and schematic diagrams of transverse sections of the chestnut stem

tions of $C$. dentata and C. crenata (Table 3). AU-17 seedlings were used as rootstocks. Ten grafts were made for each scion/rootstock combination and replicated three times as blocks, based on 5- to 8day intervals, in a randomized complete-block design. 4) The effect of different $C$. mollisima rootstocks on graft compatibility was investigated in two seedling rootstocks from AU-17 and AUHomestead. Six cultivars and selections of $C$. dentata and $C$. crenata (Table 4 ) were arranged in a $2 \times 6$ factorial experiment using a randomized complete-block design. Ten grafts of each scion/rootstock combination were replicated three times by 5 - to 8 day intervals during the grafting period.

A veneer side graft method was used in the study (Fig. 1A). The method is a modification of a regular veneer crown graft (Key, 1978). Dormant scions were grafted on actively growing rootstocks in late Mar. and early Apr. 1992. The scions and rootstocks were carefully matched at the cambial layer by grafting on nonfiber bundle sections. This avoided the phloem fiber bundles, as shown in Fig. 1B, except when intentionally matched in Expt. 2. Furthermore, all grafts were double-grafted (two scions were side-grafted separately on a single rootstock) and made by the senior author in order to minimize the experimental error caused by the grafting operation. Grafted trees remained in the containers in an outside growing area under daily sprinkler irrigation, and were fertilized with $40 \mathrm{~g}$ Osmocote 17-7-12 twice per tree in the second growing season. Data were collected when plants were growing at the end of the second growing season. All data were subjected to analysis of variance (ANOVA) with mean separation by Duncan's multiple range test using the SAS statistical system (SAS Institute, Cary, N.C.). Percentage data were arcsin-transformed before analysis.

Cambial isoperoxidase analysis. Scions and rootstocks of five successful and five unsuccessful grafts of each scion/rootstock combination were sampled for electrophoretic cambial isoperoxidase banding patterns. In cases of scion/rootstock combinations with $>93 \%$ graft success (where $<5$ unsuccessful grafts were available), all unsuccessful rootstocks were sampled and the number of successfully grafted rootstocks was increased so the sample size remained 10. Data were collected as actual counts for each banding pattern of isoperoxidase among the 10 rootstocks sampled, to evaluate the relationships between grafting success and isoperoxidase banding patterns. In addition, 20 seguin chestnut trees from each of two seguin populations from Hubei, People's Republic of China, were sampled, because seguin rootstock has proven to be completely incompatible with Chinese chestnuts (Liu et al., 1988). Extracts of active stem cambium were prepared as described by Santamour et al. (1986). Extraction buffer No. 3 was used and was recommended by Wendel and Weeden (1989). A microslab isoelectric focusing polyacrylamide gel system (Mulcahy et al., 1981) was used, and the cambial isoperoxidase banding patterns were visualized with the staining solution as described by Wendel and Weeden (1989).

\section{Results and Discussion}

Graft compatibility in Chinese chestnut. Significant differences in graft success were observed among the 15 Chinese cultivars on AU-17 seedling rootstocks (Table 1). Overall graft compatibility was high, with $\geq 67 \%$ success among 13 of 15 cultivars tested after two growing seasons. The results are similar to the success rate of intraspecific grafting in Japanese chestnut (Burnett, 1987), Chinese chestnut (Wallace, 1986), and European chestnut (Jindal and Karkara, 1991) species. The range of success rates (Table 1) is also consistent with that commonly found in the chestnut industry in China (Zhang et al., 1987). This suggests that incompatibility in Chinese chestnut is not a major cause of shortterm chestnut graft failure. Many investigations have reported graft failure of intraspecific grafting of Chinese chestnut in the United States (Hardy, 1960; Jaynes, 1963; MacDaniels, 1955; McKay, 1947). Jaynes (1979) suggested four common factors associated with chestnut graft failure: lack of winter hardiness, graft union infection by chestnut blight, poor grafting techniques, and scion-rootstock incompatibility. Winter injury- and blight infection-associated graft failure are not likely because of the mild winter climate in Alabama and lack of blight symptoms in our experimental plots.

Mismatch of phloem fiber bundles has an important effect on graft success (Table 2). The anatomical structure of the chestnut stem is unusual in that the wood is fluted or grooved, in contrast to other commercially grafted fruit and nut species. Phloem fibers develop regular tangential bands several cells in depth, alternating with bands of the soft phloem cells (Metcalfe and Chalk, 1979). This stratified phloem structure was observed by microscopic examination in all species in the present study. A very important aspect of this anatomical structure is that the stratified pattern of phloem bands forms fiber bundles in four areas of the circumference of the stem. The fiber bundles develop towards the cambium and make the periphery of the xylem fluted or grooved (Fig. 1B). This may explain why Jaynes stated that the problem of incompat- 


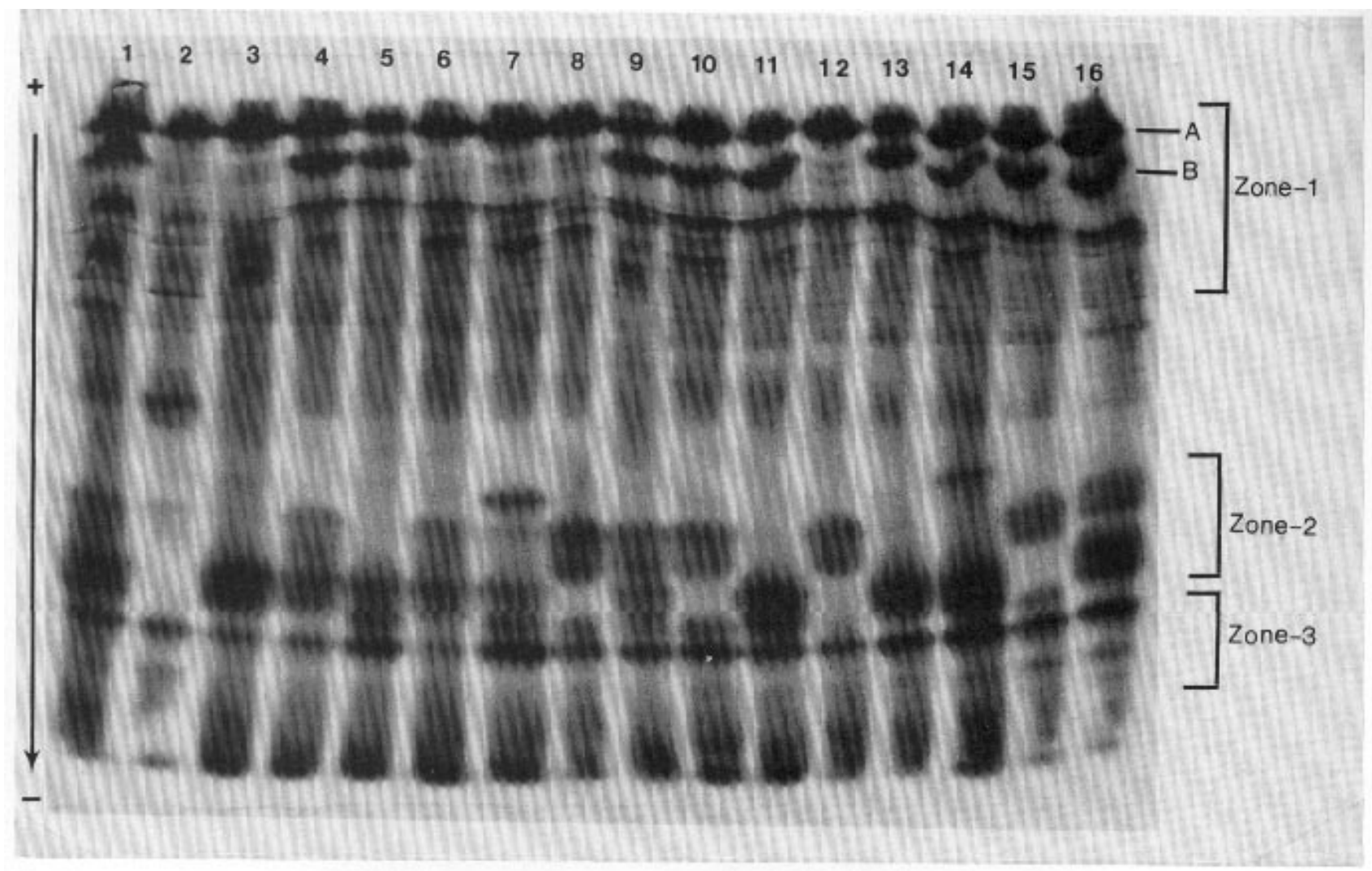

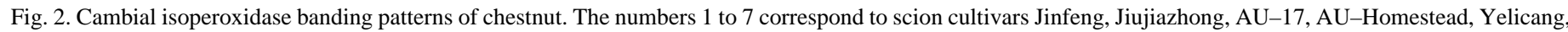
WS-R1, and WS-1, respectively; the numbers 8 to 16 correspond to seedling rootstocks from AU-Homestead.

ibility is more evident in grafting of nursery trees than in topworking of trees at least 2 years old (Jaynes, 1963). Not recognizing the fiber bundles could result in a $50 \%$ chance of making a cut on areas of the fiber bundle as shown in Fig. 1B. When seedlings are 2 to 3 years old, the fiber bundles become more distinguishable and are easier to separate during the grafting operation. An experienced grafter usually has $100 \%$ grafting success of Chinese chestnut by choosing the right technique and proper cut (Jaynes, 1963; Stoke, 1960; Woodroof, 1979).

It can still be difficult to accurately assign reasons for graft failure in chestnut. Structural defects of the graft union were observed in the grafting of pears (Proebsting, 1928) and apples (Sass, 1932). In chestnut grafting, a mass of parenchymatous tissue similarly interrupted the normal vascular connection between stock and scion when grafts were made by placing the scion on the phloem fiber bundle section of rootstock. The interruption of cambial continuity was observed in such grafts and was probably caused by a proliferation of phloem fiber tissue. Such grafts might survive for a few months and then die (Table 2). This phenomenon, classified as localized incompatibility (Hartmann et al., 1990), may more correctly be considered the result of improper grafting (Sass, 1932).

Two cultivars used in the present study do not fit this hypothesis. Cultivars Yelicang (0\% success) and Zaozhuang (40\% success) both belong to the Chang Jiang River group, which is considered the most genetically diverse of all Chinese chestnut regional groups. Yelicang, in particular, is unusually vigorous in growth, which may indicate genetic divergence from other cultivars. It is possible that in these two cases graft failure may be associated with genuine genetic incompatibility. Zhang et al.
(1987) stated that $0.5 \%$ of Chinese chestnut in China are genetically incompatible.

Interspecific compatibility and rootstock effect. Seven of the nine American chestnut selections had satisfactory graft compatibility $(\geq 70 \%)$ on Chinese chestnut rootstocks, as did five of the six Japanese chestnut cultivars (Table 3). Two unsatisfactory American chestnut selections, WS-Male sterile and WS-Curly, had a significantly lower success rate on Chinese chestnut rootstocks, suggesting a genetic difference related to graft incompatibility. These two selections exhibited specific morphological abnormalities at the graft union. Most grafts of WS-Male sterile showed swelling at the union. Some of these grafted trees were broken by wind in the second growing season and displayed a typical smooth breakage at the graft union similar to that observed in almond (Hartmann et al., 1990). The graft failure of WS-Curly was associated with cracks or lesions at the graft union.

The Japanese cultivar Kiasheng was highly incompatible with Chinese chestnut (Table 3). A marked difference in growth vigor between Kiasheng scion and AU-17 stock was observed. Kiasheng on AU-17 grew poorly and defoliated early. This phenomenon has been classified as one of the external symptoms correlated with graft incompatibility (Hartmann et al., 1990), although no graft union malformations were found in grafts of Kiasheng on AU-17. The same result was observed in an experiment grafting Kiasheng on random Chinese seedlings in the People's Republic of China, when Kiasheng was first introduced. Most of the grafted trees died gradually within 2 to 3 years (unpublished personal data).

Two putative Japanese hybrids $\mathrm{CT}^{\#}$ and $\mathrm{CT}^{*}$ tested in this study are from seeds of interspecifically open-pollinated trees of C. crenata (G. Miller, 1992, Empire Chestnut Co., Carrollton, 
Table 5. Effect of cambial isoperoxidase on grafting success of chestnuts

\begin{tabular}{|c|c|c|c|c|c|c|c|}
\hline \multirow{3}{*}{$\begin{array}{l}\text { Scion/stock } \\
\text { combination }\end{array}$} & \multirow{3}{*}{$\begin{array}{l}\text { Scion } \\
\text { band }\end{array}$} & \multicolumn{6}{|c|}{ Rootstock isoperoxidase bands } \\
\hline & & \multicolumn{3}{|c|}{ Successful } & \multicolumn{3}{|c|}{ Unsuccessful } \\
\hline & & $\mathrm{A}^{\mathrm{z}}$ & $\mathrm{AB}$ & $\overline{\mathrm{B}}$ & $\mathrm{A}$ & $\mathrm{AB}$ & $\mathrm{B}$ \\
\hline \multicolumn{8}{|l|}{ Chinese/Chinese } \\
\hline Jiaozha/AU-17 & $\mathrm{B}$ & 1 & 3 & 1 & 2 & 2 & 1 \\
\hline Jiujiazhong/AU-17 & A & 1 & 4 & --- & 2 & 2 & 1 \\
\hline Yangmaoli/AU-17 & $\mathrm{AB}$ & 2 & 5 & 3 & --- & --- & --- \\
\hline Liuyuebao/AU-17 & B & 1 & 7 & 2 & --- & --- & --- \\
\hline Yelicang/AU-17 & $\mathrm{AB}$ & --- & --- & --- & 4 & 4 & 2 \\
\hline Zaozhuang/AU-17 & $\mathrm{AB}$ & 3 & 2 & --- & 1 & 3 & 1 \\
\hline Jianding/AU-17 & A & 1 & 7 & 2 & --- & --- & --- \\
\hline Hongguang/AU-17 & $\mathrm{B}$ & 3 & 4 & 3 & --- & --- & --- \\
\hline Yanhong/AU-17 & $\mathrm{AB}$ & --- & 6 & 4 & --- & --- & --- \\
\hline Haifeng/AU-17 & $\mathrm{AB}$ & 1 & 5 & 4 & --- & --- & --- \\
\hline Jinfeng/AU-17 & $\mathrm{AB}$ & --- & 1 & 4 & 1 & 3 & 1 \\
\hline Changcibanhon/AU-17 & $\mathrm{AB}$ & 1 & 4 & --- & 2 & 2 & 1 \\
\hline Shangguang/AU-17 & $\mathrm{AB}$ & 2 & 8 & --- & --- & --- & --- \\
\hline Duangcibanhon/AU-17 & A & --- & 2 & 3 & 2 & 1 & 2 \\
\hline Zhongguohonpi/AU-17 & $\mathrm{AB}$ & 5 & --- & --- & 4 & --- & 1 \\
\hline \multicolumn{8}{|l|}{ American/Chinese } \\
\hline WS-1/AU-Homestead & A & 3 & 4 & 2 & 1 & --- & --- \\
\hline WS-1/AU-17 & $\mathrm{A}$ & 2 & 4 & 1 & 2 & --- & 1 \\
\hline WS-R1/AU-17 & A & 1 & 2 & 2 & 2 & --- & 3 \\
\hline WS-R2/AU-17 & A & 4 & --- & 1 & 1 & 2 & 2 \\
\hline WS-Curly/AU-17 & A & 1 & 2 & 2 & --- & 3 & 2 \\
\hline Shinbone/AU-17 & A & 4 & 2 & 4 & --- & --- & --- \\
\hline Shinbone/AU-17 & A & 2 & 5 & 3 & --- & --- & --- \\
\hline WS-Male sterile/AU-17 & A & 1 & 4 & --- & 3 & 1 & 1 \\
\hline WS-E2/AU-17 & A & --- & 4 & 1 & 1 & 3 & 1 \\
\hline WS-E1/AU-17 & A & 2 & 5 & 1 & --- & 1 & 1 \\
\hline Hesper/AU-17 & A & 5 & 3 & --- & 1 & 1 & --- \\
\hline
\end{tabular}

${ }^{\mathrm{Z}}$ Isoperoxidase phenotypes of rootstock seedlings.

Ohio, personal communication). Morphological characteristics such as leaf shape, burr, and nut of CT1 $1^{\#}$ and CT2 ${ }^{\#}$ appeared to be intermediate between $C$. crenata and $C$. mollissima. As shown in Table 4, the hybrids always had a significantly lower percentage of successful grafts $(<50 \%)$, regardless of rootstocks used. Jaynes (1963) indicated that graft incompatibility occurred more frequently in grafting of hybrids than in grafting of different pure chestnut species on Chinese chestnut rootstocks. During the study we also examined graft incompatibility of Chinese chestnut on European chestnut (C. sativa) seedlings and vice versa (data not shown). No Chinese scions grafted on European rootstocks survived; European scions on Chinese rootstocks had $<20 \%$ survival, with the typical symptom of the scion overgrowing the rootstock. This suggests that any rootstocks assumed to be $C$. mollissima, but which are actually a result of cross-pollination with $C$. crenata or C. sativa, could cause a serious problem in graft propagation (MacDaniels, 1956; Woodroof, 1979). Many European, Japanese, and Chinese chestnuts and their hybrids are planted in the United States (Bergnatz, 1987); therefore, nurseries should be aware of this potential problem. Rootstocks from specific Chinese cultivars can significantly affect the successful grafting of different chestnut species (Table 4), suggesting further need for selection of clonal or carefully characterized rootstock for the chestnut nursery industry.

Cambial isoperoxidase. We examined the cambial isoperoxidase patterns from 260 grafts consisting of five successful and five unsuccessful grafts from each scion-rootstock combination. Three major zones of isoperoxidase were observed (Fig. 2). Since anodal isoperoxidases reportedly regulate lignification, which can be related to graft compatibility (Buchloh, 1960; Wolter and Gordon, 1975), only an anodal zone, designated as zone 1 , was considered in this study (Fig. 2). Many bands were observed, but only two consistent bands in zone 1, referred to as bands A and B by Santamour et al. (1986), were easily identifiable (Fig. 2). All American chestnut selections had only band A and the Chinese cultivars and rootstocks had A, B (single A or B band is presented only), or AB bands (both A and B bands are presented). The third band, designated as C by Santamour (1986), was not found because of inconsistency of band expression, even though many bands were present in this area. This is consistent with the recent work by Anagnostakis (1991), who demonstrated that expression of bands $\mathrm{A}$ and $\mathrm{B}$ is controlled by a single Mendelian gene, and no $\mathrm{C}$ band was found. Santamour's report (1988) that $4 \%$ of Chinese chestnut have the $\mathrm{C}$ band was based on a study of 200 seedlings purchased from two U.S. nurseries. In contrast, the present study is based on material directly imported from representative Chinese germplasm collections or other known origins. The existence of the $\mathrm{C}$ band in material directly imported from China has not been demonstrated.

While clearly distinguishable banding patterns were resolved, no significant relationship between grafting success and cambial isoperoxidase banding patterns could be detected. Isoperoxidase bands of scions from each cultivar or selection are identical because all scions of each cultivar were collected from a single parent tree, while isoperoxidase bands of Chinese rootstocks vary because they were open-pollinated seedlings. Scions with band A could be successfully grafted on rootstocks with bands $\mathrm{A}, \mathrm{AB}$, or $\mathrm{B}$, as could scions with bands $\mathrm{AB}$ or B (Table 5). Thus, anodal peroxidase bands did not appear to be related to grafting success. This fails to confirm previous reports that cambial isoperoxidase banding patterns were related to Chinese chestnut graft incompatibility (Santamour, 1988; Santamour et al., 1986). Further, we examined 20 seguin chestnut trees from each of two seguin populations from Hubei, People's Republic of China, and found both AB ( 8 trees) and B (32 trees) banding patterns. Since rootstocks of seguin chestnut are incompatible with Chinese chestnut scions, these results do not support the possibility that these cambial isoperoxidases are major determinants of graft compatibility. In summary, the high success rates of grafting American and Japanese chestnuts on Chinese chestnut rootstocks indicate a potential for selecting Chinese chestnut clonal rootstocks. However a longterm study is needed to evaluate the compatibility of interspecific grafts. Further reciprocal grafting tests among all chestnut species would also be useful in identifying cases of real genetic graft incompatibility.

\section{Literature Cited}

Anagnostakis, S.L. 1991. Peroxidase allozyme phenotypes in Castanea and their segregation among progeny. HortScience 26:1424.

Bergnatz, B. 1987. Experience with the California chestnut industry, p. 17-23. In: M.S Burnett and R.D. Wallace (eds.). Chestnut and creating a commercial chestnut industry. Chestnut Growers Exchange, Portland, Ore.

Buchloh, G. 1960. The lignification in stock-scion junctions and its relation to compatibility. In: J.B. Pridham (eds). Phenolics in plant in health and disease. Pergamon Press, Long Island, N.Y.

Burnett, M.S. 1987. Chestnut culture and industry in China and Korea, p. 79-86. In: M.S Burnett and R.D. Wallace (eds.). Chestnut and creating a commercial chestnut industry. Chestnut Growers Exchange, Portland, Ore.

Hardy, M.B. 1960. The propagation of Chinese chestnut trees. Annu. Rpt. Northern Nut Growers Assn. 51:36-40.

Hartmann, H.T., D.E. Kester, and F.T. Davies, Jr. 1990. Plant propaga- 
tion: Principles and practices. 5th ed. Prentice Hall, Englewood Cliffs, N.J.

Jaynes, R.A. 1963. Panel on compatibility of chestnut graft. Annu. Rpt. Northern Nut Growers Assn. 51:36-40.

Jaynes, R.A. 1979. Chestnuts, p. 124. In: R.A. Jaynes (ed.). Nut trees in North America. Northern Nut Growers Assn.

Jindal, K.K. and B.K. Karkara. 1991. Chestnuts, p. 498-518. In: S.K. Mitra, T.K. Bose, and D.S. Rathore (eds.). Temperate fruits. Hort. and Allied Publishers, Calcutta, India.

Keys, R.N. 1978. Prospects for vegetative propagation in the genus Castanea, p. 10-16. In: W.L. MacDonald, F.C. Cech, J. Luchok, and C. Smith (eds.). Proc. Amer. Chestnut Symp. Morgantown, W.Va.

Lagerstedt, H.B. 1987. A review of chestnut propagation, p. 56-61. In: M.S. Burnett and R.D. Wallace (eds.). Chestnut and creating a commercial chestnut industry. Chestnut Growers Exchange, Portland, Ore.

Liu, L., J.H. Cai, and Y.H. Zhang. 1988. Chestnuts, p. 33. 2nd ed. (In Chinese.) Scientific Publishing House, People's Republic of China.

MacDaniels, L.H. 1955. Stock-scion incompatibility in nut trees. Annu. Rpt. Northern Nut Growers Assn. 46:92-97.

McKay, J.W. 1947. Results of a Chinese chestnut rootstock experiment. Annu. Rpt. Northern Nut Growers Assn. 38:83-85.

McKay, J.W. and R.A. Jaynes. 1969. Chestnuts, p. 281-285. In: R.A. Jaynes (eds). Handbook of North American nut trees. Northern Nut Growers Assn., Knoxville, Tenn.

Metcalfe, C.R. and L. Chalk. 1979. Anatomy of the dicotyledons. vol. 1. 2nd ed. Clarendon Press, Oxford.

Mulcahy, D.L., R.W. Robinson, M. Ihara, and R. Kesseli. 1981. Gametophytic transcription for acid phosphates in pollen of Cucurbita species hybrids. J. Heredity 72:353-354.
Proebsting, E.L. 1928. Further observations on structural defects of the graft union. Bot. Gaz. 86:82-92.

Rutter, P.A., G. Miller, and J.A. Payne. 1990. Chestnuts, p. 770. In: J.N. Moore and J.R. Ballington, Jr. (eds.). Genetic resources of temperate fruit and nut crops. Intl. Soc. Hort. Sci., Wageningen, the Netherlands.

Santamour, F.S., Jr., A.J. McArdle, and R.A. Jaynes. 1986. Cambial isoperoxidase patterns in Castanea. J. Environ. Hort. 4:14-16.

Santamour, Jr., F.S. 1988. Graft incompatibility related to cambial peroxidase isozymes in Chinese chestnut. J. Environ. Hort. 6:33-39.

Sass, J.E. 1932. Formation of callus knots on apple grafts as related to the histology of the graft union. Bot. Gaz. 94:364-380.

Stoke, H.F. 1961. Topworking Chinese chestnuts. Annu. Rpt. Northern Nut Growers Assn. 51:42-44.

Wallace, R.D. 1986. The Dunstan American x Chinese hybrid chestnut, Castanea dentata $\times$ C. mollissima. Annu. Rpt. Northern Nut Growers Assn. 77:13-20.

Weber, G.C. and L.H. MacDaniels. 1969. Propagation, p. 29. In: R.A. Jaynes (eds). Handbook of North American nut trees. Northern Nut Growers Assn., Knoxville, Tenn.

Wendel, J.F. and N.F. Weeden. 1989. Visualization and interpretation of plant isozymes, p. 9. In: D.E. Soltis and P.S. Soltis (eds.). Isozymes in plant biology. Dioscorides Press, Ore.

Wolter, K.E. and J.C. Gordon. 1975. Peroxidase as indications of growth and differentiation in aspen callus culture. Physiol. Plant 33:219-223.

Woodroof, F.G. 1979. Three nuts. 2nd ed. AVI Publishing, Westport, Conn.

Zhang, Y.H., F.D. Wang, X.Y.Gao, and Y.X.Zao (eds.). 1987. Chestnuts. China Forestry Publishing House, Beijing. 